\title{
Struktur dan Corak Novel-Novel Jawa Pra Kemerdekaan
}

\author{
Teguh Supriyanto dan Esti Sudi Utami \\ Universitas Negeri Semarang
}

\begin{abstract}
Abstrak
Struktur teks novel- novel Jawa Pra Kemerdekaan dibangun dari arkasemem kota -desa. Kota merupakan tempat yang ideal sementara desa tidak ideal. Dengan demikian, alur cerita umumnya memutar dari kota ke desa dan memutar kembali ke kota menuju ke arah yang ideal. Alur cerita dibangun melalui penerobosan medan semantis yang memenuhi ruang ruang artistik. Medan semantis novel-novel tersebut umumnya dikonstruksi melalui pasangan oposisi bangsawan - rakyat, laki- perempuan, tampan/cantik-buruk, kaya-miskin. Bangsawan tinggal di kota. Mereka berada di istana serta rumah-rumah mewah. Sementara desa merupakan tempat para petani dan orang orang biasa bekerja keras untuk memenuhi kebutuhannya. Corak novel Jawa Pra Kemerdekaan umumnya istana sentris dengan gaya bahasa perbandingan seperti metafora dan personifikasi. Romantisisme menjadi corak yang menonjol dengan sebaran ideologi yang berorientasi feodalistik dan romantik.
\end{abstract}

Kata Kunci: struktur ruang artistik, medan semantis, corak

\section{Abstract}

The structure and style of Pre-independence Javanese novels was built from binary opposition city-village. The city is the ideal place, while the village is not. Hence, the plot of this story was like a circle, from city to village and then went back to city. The plot was constructed by breaking semantic fields in the artistic areas. The semantic fields of the novels are generally constructed through opposition pairs, such as nobles-commoner, men-women, handsome/prettyugly, and also rich-poor. Noblemen lives in the city. They live in palaces and mansions. On the other hand, the village is a place for farmers and commoners to work hard to meet their needs. The colours of Javanese pre-independence novels usually are centric palaces with comparison language style, such as metaphor or personification. Romanticism became a prominent colours with feudalistic and romantic oriented ideology distribution.

Keywords: artistic space structure, semantic field, colour 


\section{Pendahuluan}

Penulisan sejarah sastra Indonesia selalu dikaitkan dengan peristiwa politik. Faruk (2002) mencatat bahwa sejarah sastra Indonesia tidak dapat dilepaskaan dari peristiwa politik, terutama sesudah kemerdekaan. Di lihat dari peristiwa politik yang terjadi, pengarang sastra Indonesia digolongkan menjadi angkatan empat lima (45), angkatan enamenam (66). Bahkan, sastra Indonesia kemudian ada yang menuliskan masuk angkatan reformasi (2000) an. Hal demikian ternyata mempengaruhi penulisan sejarah sastra daerah di Indonesia.

Sastra Jawa modern tidak terkecuali. Penulisan sejarah sastra Jawa modern mengikuti jejak sastra Indonesia yang dikaitkan dengan peristiwa politik (Widati, dkk, 2001). Sungguhpun demikian, Faruk (2002) memberikan peluang ruang kosong bahwa penulisan sejarah sastra Indonesia tidak harus dikaitkan dengan peristiwa politik, meskipun tidak dapat disangkal bahwa perkembangan sastra Indonesia tidak dapat dilepaskan dengan peristiwa politik di Indonesia. Cara pandang Faruk ternyata sejalan dengan periodisasi sastra Jawa klasik ( sastra Jawa Kuno dan Jawa Pertengahan serta sastra Jawa Baru) yang didasarkan pada corak bahasa dan gaya pengarang (Zoetmulder, 1984).

Yang menarik dari laporan hasil penelitian Faruk (2002) dan Sri Widati (2001) memberikan peluang untuk menuliskan kembali sejarah sastra baik sastra Indonesia maupun sastra Jawa modern. Namun, yang perlu dicatat adalah bagaimana penulisan sejarah sastra Indonesia modern dimulai? Apakah penulisan sejarah sastra dimulai dari setelah kemerdekaan, atau mulai munculnya gejala sastra Indonesia yang ditulis dalam bahasa Melayu? Novel-novel yang terbit sebelum kemerdekaan dan yang dibaca kaum terpelajar dicetak oleh lembaga Balai Pustaka, sebuah lembaga penerbnitan milik pemerintah kolonial. Dengan demikian, warna politik kolonial ikut menentukan apakah novel sastra Indonesia modern itu layak diterbitkan dan dibaca masyarakat. Hal demikian sangat mungkin berlaku bagi sastra daerah termasuk di dalamnya sastra Jawa Modern. Novel-novel Jawa terbitan Balai Pustaka dimungkinkan terbelenggu pascakolonial karena diterbitkan Balai Pustaka.

Sebagaimana dilaporkan Faruk (2004) bahwa diciptakannya KITLV (Koninkljk Instituut voor Taal-Land en Volkenkunde) yang sekarang bernama Balai Pustaka tersebut merupakan usaha-usaha dalam rangka hegemoni kekuasaan pemerintah kolonial. Hal ini juga bertujuan untuk memperlemah kaum pribumi melalui karya sastra. Badan ini sangat mendukung wacana 
ketimuran yang dicipta kaum oriental untuk memperlemah kaum pribumi. Cerita wacana ketimuran tentang pribumi dipakai kolonial untuk mengambil kebijakan tertentu di suatu wilayah tertentu.

Faruk lebih lanjut melaporkan bahwa sastra Indonesia modern (novel-novel Indonesia tradisi Balai Pustaka dan Non Balai Pustaka) ternyata terbelenggu oleh pascakolonial dengan ideologi romantik. Apakah pandangan romantik itu juga melanda dan memepengaruhi sastra daerah di Indonesia, termasuk sastra Jawa PraKemerdekaan? Pertanyaan demikian menjadi wajar karena karya sastra Jawa Modern PraKemerdekaan kebanyakan diterbitkan oleh penerbit pemerintah kolonial (dalam hal ini Balai Pustaka), sebagaimana sastra Indonesia. Alasan kedua adalah dari segi karakteristik sastra Jawa modern sangat berbeda dengan sastra Indonesia modern yang pada masa PraKemerdekaan cenderung didominasi oleh pengarang yang berasal dari suku Melayu, meskipun banyak juga hasil karya sastra Indonesia dari pengarang Jawa.

Santosa (2....) mencatat bahwa tonggak kelahiran teori postkolonial ditandai dengan terbitnya buku Edward W. Said (1978), Orientalism. Tesis utama buku karya Said tersebut menggunakan pendekatan hubungan antara kekuasaan dan pengetahuan. Sebagaimana diantarkan oleh Michael
Foucault dalam bukunya, The Archeology of Knowledge(1972) dan Discipline and Punish: The Birth of the Prison (1977), kaum orientalis berpendapat bahwa masalah studi ilmiah Barat mengenai Timur tidaklah semata-mata didorong oleh kepentingan pengetahuan, tetapi juga kepentingan kolonialisme. Pengetahuan bagi kaum Orientalis adalah untuk mempertahankan kekuasaanya, yakni pengetahuan yang dipenuhi dengan visi dan misi politis ideologis. Hubungan terjajah dan penjajah sangatlah kompleks. Pandangan Said tersebut seolah-olah menyuarakan secara eksplisit apa yang terpendam dalam kesadaran banyak orang, terutama orangorang di negara bekas jajahan Barat, yang kini disebut sebagai "dunia ketiga", untuk bangkit berjuang menemukan kesadaran dengan menuntut keadilan dan kesetaraan. Gugatan yang menekankan kebebasan dan penolakan atas segala pemikiran atau kekuasaan hibridasi, misalnya, menemukan formulasinya yang paling mantap dalam pemikiran filsuf seperti Jacques Derrida dan Michael Foucault. Bukanlah suatu kebetulan apabila Gayatri C. Spivak, tokoh yang terkenal karena kontribusinya yang besar dalam membangun kajian postkolonial secara terus-menerus, menulis pengantar yang demikian panjang untuk buku Jacques Derrida, Of Grammatology, (1982). Dalam pengantar buku tersebut pada dasarnya Spivak menolak segala kekuasaan yang 
menghambat dan membatasi, sekaligus mengungkapkan pengutamaannya atas kebebasan. Masyarakat yang tertekan dan terjajah, subaltern, harus berbicara, harus mengambil inisiatif, dan menggelar aksi atas suara mereka yang terbungkam.

Penelitian ini mencoba menjawab masalah utama yaitu apakah novel-novel Jawa Modern Pra Kemerdekaan terbelenggu oleh ideologi pascakolonial? Untuk dapat menjawab permasalahan tersebut perlu dipecahkan dahulu struktur dan corak novel karena melaluinya dapat ditemukan ideologi apa yang ada dan yang menghegemoni novel. Oleh karena itu, masalah pertama yang harus dipecahkan adalah bagaimana struktur novel dan bagaimana corak novel. Peneliti menggunakan pendekatan literer dengan metode dokumentasi sebagai langkah awal untuk mengumpulkan data novel, selanjutnya digunakan pendekatan objektif sebagaimana disarankan Abrams (1984) untuk membongkar teks.

Metode yang digunakan untuk membongkar dan analisis teks adalah metode struktural semiotik dari Jurij Lotman (1972) karena metode yang didasarkan teori ruang artistik Lotman mampu mengungkap ideologi teks. Melalui analisis semiotik model Lotman dapat diketahui struktur teks, dalam hal ini sudut pandang novel, alur, latar sosial dan corak novel dilihat dari bahasa dan gaya bahasa.

\section{Hasil Dan Pembahasan}

\subsection{Hasil}

Novel- novel yang terkumpul merupakan sumber data penelitian sastra. Sebelum dianalisis terlebih dahulu sumber data tersebut diverifikasi mulai dari pertanyaan apakah benar pengarang novel tersebut dan terutama tahun terbit. Mengapa demikian? Seringkali sebuah novel merupakan novel tua namun baru diterbitkan beberapa tahun kemudian atau mungkin merupakan cetakan yang ke sekian. Novel yang berjumlah 17 buah tersebut merupakan hasil verifikasi dari 35 buah novel yang terkumpul. Namun, sisanya kebanyakan novel terbitan setelah kemerdekaan bahkan banyak yang terbit sekitar tahun 60-an.

Setelah diverifikasi selanjutnya sumber data diklasifikasi. Cvaranya dengan membaca novel-novel tersebut diketahui tema-tema yang dominan. Dari sejumlah 17 sumber data ditemukan tiga (3) klasifikasi tema novel, yaitu (1) kisah perjalanan, (2) percintaan, dan (3) cerita misteri.

\subsection{Pembahasan}

\subsubsection{Struktur Teks}

(1) Alur

Setelah melalui verifikasi dan 
klasifikasi sumber data, langkah selanjutnya melakukan analisis data. Yang pertama (1) melalukan analisis struktur teks dan kedua (2) analisis corak teks.

Alur cerita novel-novel Jawa PraKemerdekaan dapat dikatakan memutar. Umumnya cerita dimulai dari suasana di kota Surakarta dan sekitarnya, kemudian pelaku atau tokoh pergi ke luar kota. Tokoh RM.Sutanto dalam Ngulandara mengembara ke Parakan, RM Riyanto dalam Serat Riyanto keluar ke Boyolali, Soewarso dalam Soewarso-Warsijah ke Wonogiri. Begitu juga dalam novel yang lain, umumnya tokoh bergerak dari kota besar Surakarta menyebar ke luar kota dan pada akhirnya kembali lagi ke kota. Alur yang demikian ternyata menjadi trend novel-novel terbitan Balai Pustaka pada awal-awal menjelang kemerdekaan. Misalnya dalam novel sastra Indonesia seperti Sitti Nurbaya, alur novel ini juga memutar kembali ke titik awal. Ada satu novel yang meskipun kembali ke Surakarta pada akhirnya ditempatkan di luar kota (Kedungwuni/ Pekalongan). Namun demikian, di akhir cerita diceritakan kedua mempelai setelah menjalankan jabatannya sebagai Wedana di Kedungwuni ditimbali kembali ke Surakarta.

Kutipan berikut menunjukkan alur cerita yang memutar.
( 1 ) Kacariyos,...R M Riyanto sampun dhiwasa...Keng Ibunipun sakelangkung susah.....menapa malih Riyanto asring tindakan wayah dalu...(Ke Boyolali)...ing salajengipun R.M Riyanto jumujug dalemipun Dipati Paramayoga ing Kepatihan.. (SR,1920).

(Terceritakan, RM Riyanto sudah dewasa....Ibundanya sangat sedih... apalagi Riyanto sering pergi malam hari...(ke Boyolali)...dan selanjutnya RM. Riyanto menuju ke rumah Dipati Paramayoga di kepatihan,,,)

\section{( 2 ) Kjai Moeslim ikoe bangsa} ngoelama, banget moengkoele lan netepi saraking agama. Jen bengi kjai Moeslim gelem moelang anak-anake tanggane.......Kjai Moeslim anake kabeh sewelas, nanging sing lestari oerip moeng teloe lanang kabeh... Sing Pembarep Djenenge Sardjana, sing panggoeloe Soedjana, sing woeragil Waskita...(TDM, 1932:3)

(Kiai Muslim itu seorang Ulama, sangat soleh dan bertaqwa dalam menjalankan agamanya. Jika malam Kiai Muslim bersedia mengajar anakanaknya tetangga,,,Kiai Muslim memiliki sebelas anak, namun yang hidup hanya tiga dan laki-laki semua... Yang sulung bernama Sarjana, nomer dua Sujono, dan bungsu bernama Waskita)

( 3 )Tjekake remboeg ikoe wis mateng. Esoeke kabeh boedhal....Sedje dina sadoeloer teloe lan bodjone pada tilik woing toewane kjai Moeslim, katemoe slamet, andadekake boengahing tine... (TDM, 1932:100)

(singkat cerita sudah pasti. Paginya mereka semua pergi. Suatu hari tiga bersaudara itu dan istrinya pergi menengok orang tuanya, yaitu Kiai Muslim. Mereka bertemu semua selamat dan membuat mereka

Bergembira...)

Kutipan (1) diambil dari cerita roman Serat Riyanto karangan RB Soerlardi terbitan tahun 1920 dari balai Pustaka. Tokoh utama roman (istilah roman dipandang sama dengan 
novel) ini adalah RM (Raden Mas) Riyanto, putra tunggal dari Pangeran Natasewoyo. Cerita diawali dari paparan deskripsi tokoh utama, yaitu Riyanto. Ia digambarkan sebagai seorang pemuda yang pandai, bagus, dan sangat santun budi bahasanya. Dia dipersodarakan dengan Raden Ajeng Maryam, sepupunya dari pihak ibunya. Riyanto sangat dimanjakan namun Riyanto menjadi pemuda yang sangat sederhana. Diceritakan setiap malam Riyanto pergi berkelana. Kelakuan Riyanto menimbulkan kekhawatiran ibundanya yang sangat takut terhadap kelakuan Riyanto ke hal-hal yang tidak diinginkan. Ibundanya sebenarnya sudah menjodohkan Riyanto dengan saudara ibunya yaitu anak dari Dipati Paramayoga. Pada suatu hari di sebuah pasar malam Riyanto menolong seorang wanita cantik di saat terjadi kebakaran. Sejak saat itu Riyanto dirundung rindu karena putri yang ditolongnya tidak mau mengaku siapa dan dari mana asalnya. Riyanto berkelana dan mengembara sampai ke Boyolali dan daerah di luar istana. Namun, Riyanto akhirnya kembali ke Surakarta ke rumah pamandanya Dipati Paramayoga. Di Kadipaten itulah dia ketemu dengan anak perempuan yang ditolongnya yang ternyata anak dari Dipati Paramayoga, yaitu Raden Ajeng Srini. Riyanto akhirnya menikah dengan Srini. Dari paparan tersebut disimpulkan bahwa alur cerita memutar dari istana keluar istana dan kembali lagi ke istana.

Kutipan kedua (2) dan ketiga (3) diambil dari novel yang berjudul Tri Djaka Moelja, terbitan Balai Pustaka tahun 1932) yang ditulis oleh M.hardjadisastra. Diceritakan bahwa Kiai Muslim mempunyai sebelas anak dan yang hidup tinggal tiga orang, Sarjono, Sujono, dan Waskita. Ketiga anaknya mengembara sampai mereka menemukan kebahagiaan sendiri-sendiri. Meskipun Kiai Muslim merupakan keluarga yang kaya dia tidak pernah mendidik anak-anaknya menjadi anak yang manja. Mereka suka bekerja dan hidup sederhana. Di akhir cerita mereka bertemu. Mereka sudah memiliki pekerjaan dan sudah beristri. Disepakati mereka pulang bersama istri-istrinya kembali menemui Kiai Muslim.

Alur melingkar juga tampak dalam novel Ngulandara karangan Margono Djajaatmadja. Diceritakan bahwa Keluarga Den Bei Asisten Wedana di Ngadiraja mengalami musibah mobil yang dikendarai mogok di daerah Parakan. Den Ayu dan Den Ajeng Tien berada di dalam mobil dari mulai jam lima sore sampai jam 9 malam. Kebetulan Rapingun, sopir mobil buick milik pedagang Cina di Parakan lewat dan berhasil menolongnya. Alur berjalan lurus. Rapingun akhirnya diterima menjadi sopir pribadi dalam keluarga Den Bei Asisten Wedana di Ngadirejo. Karena kelakuan dan 
budi bahasa Rapingun yang sangat halus serta Rapingun sangat paham terhadap unggah-ungguh keluarga Den Bei Asisten sangat sayang dan bahkan diangkat seperti anaknya sendiri. Rapingun pada suatu hari menolong Raden Ajeng Tien dari godaan lelaki di Magelang. Dalam kondisi sakit, Raden Ajeng Tieng menaruh curiga kepada Rapingun yang sangat mirip dengan foto yang ditemukan Tien di saku baju lemari Rapingun. Tien curiga bahwa Rapingun adalah Raden Mas Sutanto. Sebelum terbuka, Rapingun meninggalkan keluarga Asistenan. Cerita terus berkembang sampai akhirnya terjadi peristiwa di Pekalongan. Den Bei Asisten Wedana mengunjungi saudaran ya Den Mantri Guru. Di sana mereka bertemu dengan Rapingun yang sebenarnya bertama RM Sutanto yang sudah bekerja di kabupaten Pekalongan. Den Bei Asisten sudah diangkat menjadi wedana di Kedungwuni. Di Akhir cerita Rapingun yang bernama asli RM Sutanto menikah dengan Ajeng Tien dan tinggal di Pekalongan dan Kedungwuni.

Supaya hidup enak dan terhormat, orang harus ke kota. Berbagai cara seperti ngenger, sekolah, ikut saudara dilakukan orang yang berasal dari desa supaya memperoleh dan mampu mengangkat derajatnya. Sebaliknya, orang kota dalam hal ini para priyayi untuk memperoleh martabat mereka harus mengembara ke desa-desa dengan berbagai cara (ngulandara). Setelah memperoleh pengalaman mereka akan kembali ke kota menduduki jabatan barunya. Tokoh laki laki pastilah tampan berasal dari kaum bangsawan. Ia pergi mengembara ke desa. Selanjutnya kembali ke kota dengan gadis cantik pilihannya.

\section{(2) Latar Cerita}

Latar cerita dalam novel- novel Jawa Pra-Kemerdekaan didominasi di wilayah Surakarta dan sekitarnya. Tokoh didominasi berasal dari Surakarta dan mengembara di wilayah sekitarnya, seperti Temanggung, Wonogiri, Parakan, Pekalongan, Semarang, Boyolali, Tengaran, Klatin, Sragen, dan Madiun. Para tokoh selalu mengenakan asesoris pakaian adat Jawa dan didominasi pakaian kasatriyan. Latar sosial yang tergambar dalam novel yang tertinggi berasal dari stratifikasi keluarga bangsawan yang menduduki derajat Raden Mas, seperti Raden Mas Riyanto, Ramen Mas Duryat, Raden Mas Sutanto. Kemudian tokoh juga banyak berasal dari stratifikasi sosial Ngabean, seperti Den Bei dalam cerita Ngulandara, Soewarso-warsijah, Ni Wungkuk. Latar sosial.

Latar sosial yang umum dipaparkan dari seputar tokoh utama. Umumnya tokoh ujtama berasal dari golongan masyarakat priyayi dari Surakarta. Meskipun demikian, ada 
novel seperti Ni Wungkuk bukan berasal dari kalangan priyayi namun demikian bercerita sekitar kebijakan Sunan membuat sodetan kali Pepe di Surakarta untuk mengatasi banjir. Ada juga, novel yang berlatar pedesaan dan peristiwa kejadian berada di luar kota Surakarta, namun demikian tokoh utama berasal dari Surakarta (menyamar).

Membaca novel terbitan Balai Pustaka peneliti berkesimpulan bahwa novel disusun pada zaman kerajaan Surakarta hadiningrat masa pemerintahan Pakoe Boewono ke XI menjelang PB XII. Pada masa tersebut kondisi masyarakat Surakarta mengalami masa peralihan yang sebelumnya dipimpin raja yang terkenal wicaksana dan kaya raya. Dapat dikatakan zaman PB X merupakan zaman keemasan Karaton Kasunanan Hadiningrat. Selanjutnya pemerintahan jatuih ke tangan putranya yang saat diangkat masih sangat muda. Kebudayaan Barat terutama Belanda sangat kuat melanda kebudayaan Jawa terutama masuk ke kalangan istana di Mangkunegaran serta sebagian di kehidupan para Pangeran Karaton Surakarta. Pesta dansa dengan minuman wiski sangat umum terjadi di kalangan bangsawan. Kondisi demikian menjadikan para putra putri sentana mulai cenderung melonggarkan ikatannya dengan tradisi aturan kraton dan Kadipaten yang sangat ketat. Kecemasan inilah yang menjadikan munculnya banyak novel Jawa
Pra-Kemerdekaan yang mengangkat tema didaktis untuk para putra putri keturunan Raja.

Alat-alat transportasi masih didominasi kapal (kuda) dan ada juga kereta api jurusan Jogja-Solo. Kendaraan kereta api muncul ketika tokoh Soewarso disuruh menjemput dokter kandungan di wilayah Mangkunegaran ternyata dokternya sedang pergi. Soewarso dengan berbekal nekad akhirnya naik kereta api ke Yogyakarta menemui dokter satusatunya yang ada di kota itu. Selain itu, kendaraan otto juga mulai dikenal, terutama dalam cerita Ngulandara.

\section{(3) Sudut Pandang}

Sudut pandang yang digunakan pengarang didominasi sudut pandang orang ketiga maha tau. Perhatikan kutipan berikut ini.

Rapingun bocah kang sregep lan baud ing pakaryan apa wae Nyah.

Iya..aku ngerti bu Bei.. Wis suwe melu aku..ngrumat otto lan kapal saya maneh...Rapingun..bocah kok lehe pinter...Hel, jaran sing paling

angel..bisa nurut..

(Rapingun anak yang rajin dan pandai dalam setiap pekerjaan apapun

Nyah. Iya Bu Bei aku paham. Sudah lama ikut saya merawat mobilku dan

kudaku. Ia memang anak yang pintar dan berani. ..Hel, kuda yang sangat liar dapat patuh)

....wonten priyantun ingkang mursid...putra Pangeran Natasewaya...dhasare bagus lan pinter ing tata krami..gek 
sapa kae maau ya piyayine...kok ngelaam-elami..temen...

(...ada seorang bangsawan yang santun dan pandai...anak Pangeran

Natasewaya...anaknya memang cakap dan sangat santun... siapakah dia itu ya yang ganteng itu...kok sangat menambat hati...)

Kutipan pertama diambil dari data Ngulandara sedangkan kutipan kedua diambil dari Serat Riyanto.menunjukkan betapa pengarang maha tau dengan meletakkan sudut pandang pada para tokohnya. Di waktu lain, pengarang sering merefleksikan dirinya sebagai tokoh yang paling tau untuk menilai tokoh lain. Suatu ketika pengarang dapat menjadi bapaknya Warsijah dalam novel Soewarso-Warsijah atau dapat pula menjadi pengarang maha tau melebihi ahli paranormal ketika menceritakan tokoh $\mathrm{Ni}$ Wungkuk dalam novel Ni Wungkuk Bendo Growong.

Kutipan berikut menjelaskan sudut pandang maha tau dari pengarang.

( 1)...Pantjenipun eman-eman sanget, ndara. Menika kapal sae saestoe. Kowe kok ngreti nek iki djaran apik?

Inggih, tiyang roemijin bapa adalem gadhah dhokar sewan, dipoen koesiri pijambak.

Sok ngonoa kowe ja wis koelina menjang djaran?

Inggih, sawatawis.

Noenggang ja pinter?

Inggih saged sawatawis. Mila jen kepareng badhe dalem tjobi....(hlm 28)

( Sebenarnya sangat sayang, Tuan. Itu kuda yang bagus. Kamu kok tau bahwa itu

kuda yang bagus?. Iya Tuan, dulku bapak saya memiliki dokar (sado) untuk disewakan dan disopiri sendiri. Jika demikian kamu berarti sudah terbiasa dengan kuda?

Ya Tuan, meskipun sedikit tau. Apa menaiki kuda juga bisa? Iya Tuan, sedikit bisa.Jika diperkenankan saya akan mencobanya Tuan)

( 2)Rapingoen saweg roemaos lan mangertos poenapa ingkang dipoen gegoedjeng dening raden adjeng Tien, mila ladjeng toemoet goemoedjeng semoe rikoeh lan getoen. Sareng sampoen mendha ladjeng ngatoeri katrangan: Anoe kok, ndara, leresipoen Antaredja Gathotkatja, tijang ndara ingkang lepat, saweg doemoegi "thut" kok nothok kori”...Akoe ora loepoet, wong olehkoe ngenteni nganti sak dhandhanggoela, djare...(82).

(Rapingun baru merasa dan mengerti apa yang ditertawakan oleh raden ajeng Tien, karenanya dia ikut tertawa meskipun tersipudan sesal. Setelah sudah reda baru memberikan jawaban: Anu kok, ndara, sebenarnya Antareja gatotkaca, kan ndara putri yang salah la karena baru sampai situ ternyata ada bunyi ketokan pintu. Aku ndak salah ya karena sebenarnya aku sudah menunggu sebait tembang) 
( 3 ) Dereng ngantos tamat pamaosipoen, raden ajoe asisten wedana sampoen brebel-brebel ngedalaken loeh. Raden adjeng Tien maos kalijan katja-katja. Den bei asisten wadana dheleg dheleg. Ladjeng ngandika: Botjah iki. Wis wiwit dhek ketemoe sepisan akoe goemoen banget menjang dheweke.

Den ajoe asisten wedana njambeti: Akoe ja goemoen banget! Djadjal ing ngendi ana botjah kaja Rapingoen!"... (101-102).

(belum sampai tamat membacanya, raden ayu asisten wedana sudah mencucurkan air mata. Raden ajweng Tien juga membacanya sambil menangis. Den Bei Asisten Wedana terdiam membisu. Selanjutnya berkata: Anak ini. Sejak mulai kita menemukannya aku sudah mengaguminya. Den Ayu Asisten Wedana juga menyahut, aku juga mengaguminya coba,,,dimana kita bisa menemukan anak seperti Rapingun?)

( 4) Bareng wis bengi toeroene Endra kapenak banget, djalaran kadjaba kesel mentas leloengan adoh golek dagangan, atine ajem banget, awit ora ana kang dadi roebedaning pamikire. Beda banget karo bapak iboene Endra, sawengi moepoet ora bisa toeroe, anggagas marang anake lan keprije jen dina sesoek ana kantoraning anake nemoni lelakon kang ora dadi pangarep-arepe. Sadhela-sadhela tansah angoendjal napas, lan nenoewoen marang goesti
Allah kaloepoetna saka djeneng kang ala banget...(hal.8 Gawaning wewatekan, Koesoemadigda.)

(Setelah sudah larut malam, tidurnya Endra sangat nyenyak sebab di samping memang capai karena baru saja bepergian jauh mencari barang dagangan hatinya merasa tenteram, sebab sudah tidak ada lagi yang menyusahkan dan merisaukan. Hal ini sangat berbeda dengan ayah ibunya Endra. Semalaman mereka tidak bisa tidur, memikirkan anaknya dan bagaimana jika besok pagi anaknya di kantor menemui hal-hal yang tidak diinginkannya. Sebentarsebentar menghela napas panjang dan memohon doa kepada Allah untuk dijauhkan dari segala mara bahaya.)

Kutipan (1) diambil dari Ngulandara. Pengarang maha tau dengan meletakkan sudut pandang orang ketika pada diri tokoh. Rapingun menjadi tokoh refleksi pengetahuan pengarang mengenai pengetahuan kuda. Tokoh Rapingun menjadi sangat cerdas dalam urusan mobil mogok, mengetahui katuranggan seekor kuda, paham segala urusan kantor. Namun, di sisi lain pengarang menjadikan tokoh Rapingun sebagai seorang abdi yang sanagat rajin. Segala perabot rumah tangga yang sudah tidak terpakai dia bersihkan. Pada suatu ketika dia menemukan pelana kuda yang belum pernah digunakan.

Kutipan ke (2) menunjukkan tiba tiba 
pengarang mencoba menjadi tokoh yang memiliki perasaan ingin tau yang sangat besar. Di sisi lain ia juga bisa merubah dirinya menjadi tokoh yang ingin mempertahankan identias supaya tidak diketahui oleh keingintahuan tokoh lain, betapapun sulitnya. Tokoh Tien sebenarnya sudah hampir mendekati kebenaran identitas tokoh Rapingun. Tien mampu mengungkapkan dan memilih kosakata untuk menjebak Rapingun supaya mau mengungkap dirinya. Namun, tiba- tiba pengarang beralih rupa menjadi tokoh Rapingun. Dengan piawai Rapingun terselamatkan identitasnya. Tokoh Rapingun ikut tertawa melihat polah Tien (kutipan kedua) untuk menyembunyikan identitasnya sebelum dia berpura bingung menghadapi tokoh Tien.

Kutipan ke tiga (3) menunjukkan betapa pengarang mampu menyembunyikan kemahatauannya melalui tokoh yang tidak dihadirkannya, yaitu Rapingun. Meskipun demikian, tanda-tanda kemahatauannya terlihat melalui jejak sikap yang dapat ditangkap oleh tokoh seperti Den Bei Asisten Wedana dan Den Ayu. Namun mereka masih saja terkecoh. Bahkan, Tien yang sudah mulai jatuh cinta juga tidak mampu menilai dan menduga kelakuan Rapingun.

Kutipan (4) menunjukkan betapa pengarang mampu menunjukkan kemahatauannya sebagaimana kutipan ke
(3) pada novel yang berbeda, yaitu novel Gawaning Wewatekan karya Koesoemadigda. Gaya kepura-puraan ditunjukkan oleh tokoh Bapaknya Endra untuk mengelabui Endra yang mampu memberikan sejumlah uang yang memang sangat dibutuhkan oleh bapaknya.

\subsubsection{Corak Teks}

Corak novel dapat dilihat melalui analisis gaya bahasa.

\section{(1) Gaya Bahasa Kias}

Gaya bahasa kias, seperti metafora dan hiperbola sangat mendominasi novel-novel terbitan Balai Poestaka. Sebaliknya, gaya retoris cenderung sedikit.Novel Tri Djaka Moelja karangan M.Hardjadisastra misalnya, merupakan cerita dengan gaya bahasa kias metafora. Dimulai dari judulnya, yaitu Tri Djaka Moelya, yang menceritakan ketiga putra dari Kiai Muslim yang pergi dari rumah mengambara. Akhirnya mereka dipertemukan dengan kondisi yang saling melengkapi. Hidup itu bagi lelaki muda memenuhi tiga cita-cita, kedudukan, harta, dan jangan lupa selalu taqwa kepada Sang Pencipta. Metafora ini digambarkan pada ketiga putra Kiai Muslim. Anak pertama di akhir cerita menjadi Den Bei Wedana dan mendapat istri putri Kangjeng Bupati, Putra kedua mendapat istri cantik dan anak saudagar kaya, sedangkan yang terakhir menjadi 
Kiai yang memiliki banyak santri hidup selalu memberi pertolongan kepada siapapun yang membutuhkan pertolongan.

Sasoewene leloenggoehan Sardjana celathu: Soewe-soewe akoe kok ora krasan ana kene, kepengin arep loenga golek gawean. Soedjana njauri: Sing

kok senengi njamboetgawe apa kang. Apa dadi mandhor teboe, apa djoeroe toelis, apa toekang oekoer?..

Doedoe kuwi, satemene ana pegawean sing dak impi-impi wiwit tjilik, akoe

kepengin dadi prijaji pangreh pradja...(TDM, hal 7).

(selama duduk Sarjono berkata: lama-lama kok aku tidak kerasan, kepingin pergi mencari pekerjaan. Sujono menjawab: yang kamu sukai pekerjaan apa kang.Apa menjadi mandor tebu atau sekretaris atau teknik sipil? Bukan itu, sebenarnbya ada pekerjaan yang paling aku sukai sejak kecil, aku kepingin menjadi pegawai negeri di pemerintahan.)

Kutipan di atas menggambarkan keinginan anak-anaknya Kiai Muslim setelah mereka selesai diajaroleh bapaknya. Sardjana, Sudjana, dan Waskita saling mengungkapkan keinginannya setelah menjadi dewasa.

Novel Ngulandata, Serat Riyanto, Pantja-Kawarna dan lainnya lebih bersifat metaforis. Novel yang terakhir disebut lebih bergaya metaforis untuk menggambarkan jalannya kehidupan di dunia. Berbagai cerita binatang ditampilkan untuk menggambarkan sifat dan keinginan manusia hidup. Kutipan berikut menggambarkan penjelasan di atas.

Ketek tjelathoe maneh: Jen mangkoono ija ta. Koepoe, kowe bagejanmoe apa?

Koepoe mangsuli: $O$, Kowe doeroeng pada ngreti, akoe kan bakal milihake poetri jlaon garwane goesti, ja ikoe sing $m$ oendhoet kembang ragaina, endi sing geloengane dak enjkoki, ja ikoe poetrane sang praboe.(PKhlm 24).

(Kera berkata lagi: Jika demikian, baiklah. Kupu, kamu bagianmu ngapain?

Kupu menyahut, O kamu belum tau ya, aku akan memilihkan putri untuk menjadi istrinya sang pangeran, itulah yang mengambil bunga ragaina, mana yang gelung rambutnya, itulah putinya sang raja.)

\section{(2) Sarana Retoris}

Novel-novel yang terbit di luar tradisi Balai Pustaka umumnya menggunakan sarana retoris lainnya semacam sinekdok dan citraan. Bahasa yang dipilih lebih ke gaya realis serta kontradiktif.

(1) Katjarita, olehe babad Pandhanwangi wis rampoeng, nanging isih kewoehan anggone nggarap lan pamanggone, banjoer ngetokake kasektene: ndjedjak lemah ping teloe ora ambegan, sanalika djleg ana omah pating djenggeleg.

Pandhanwangi saiki ora kewoehan olehe bakal toeroe..(PK, hlm 35) 
(Terceritakan, dalam membuka hutan Pandanwangi sudah selesai tetapi masih masgul membuat dan mendiaminya, oleh karena itu dia mengeluarkan

kesaktiannya. Menjejak tanah tiga kali sambil tidak bernapas, mendadak jleg ada sebuah rumah yang besar, pandhanwangi sekarang sudah tidak bingung lagi menghadapi tidur)

(2) Babah Dengkek: Ija, Den. Satemene ija mangkono. O, Allah, Den.akoe toeloengana ta, mengko rak tak wales betjik ta, Den. Sindoe: Anaa kene bae dhisik, nanging adja loenga saka koersi lo. Akoe tak ngloengakake poelisikoe kang meloe maoe....(GW, hlm.41).

(Babah Dengkek: Iya Den, Sebenarnya memang begitu. O Allah, Den, tolonglah aku, nanti saya balas kebaikan anda itu ta Den. Sindu: Kamu jangan beranjak dari kursimu, di sini dulu. Saya akan membikarkan polisi itu pergi yang ikut denganku itu)

Kutipan pertama (1) bergaya realis dan kutipan kedua (2) bergaya kontradiktif. Apa yang dilakukan tokoh Sindu berkebalikan dengan kenyataan. Babah Dengkek tetap dijadikan sumber uang baginya. Dengkek pedagang candu gelap, sementara Sindu kecanduan main.

Kutipan (1) diambil dari novel Pantja Kawarna karya Soekarno terbitanBalai Pustaka 1920, kutipan kedua diambil dari novel cerita Gawaning Wewatekan karya Koesoemadigda terbitan tahun 1932. Kutipan berikut (3) menerangjelaskan gaya bahasa metaforis yang memperbandingkan bangsawan-kaya dengan pandangan romantik dan ideal bahwa seorang bangsawan harus menikah seorang putri bangsawan supaya mampu mengangkat derajat klas sosial.

Raden Nganten wau ngrembagi dhateng Mas Rangga, sarehning sapunika sampun dados priyatun: supados rabi malih angsal putraning priyantun, sokur bagi angsal putri.

(raden Nganten selanjutnya berbincang dengan Mas Rangga, Karena sekarang sudah menjadi priyantun atau bangsawan sebaiknya sekarang menikah lagi dengan putri sukjur putri bangsawan) (novel SuwarsoWarsiyah, 1926: 3-4). 


\section{Penutup}

Sebagai penutup dapat disimpulkan bahwa struktur dan corak novel-novel Jawa Modern Pra-kemerdekaan dibangun melalui alur yang memutar kembali ke titik awal. Alur tersebut dijalin melalui tokoh yang berlatar kota dan desa. Konflik sangat normatif dan berkisar seputar persoalan keluarga terutama cinta dan kedudukan, petualangan, dan cerita misteri. Latar kota menjadi tujuan para tokoh yang umumn ya ditem ukan dalam novelnovel Jawa. Kedudukan sebagai bangsawan dan pangreh praja menjadi tujuan hidup yang ideal. Hal ini dapat dilihat dalam penggunaan sudut pandang yang cenderung romantik.

Corak bahasa lebih didominasi oleh gaya metaforis dan personifikasi, meskipun melalui pilihan gaya realis dan paradoks sebenarnya tersirat gaya metaforis. 


\section{Daftar Pustaka}

Abrams. MH.1984.The Miror and The Lamp. Bloomington: Kegan Paul.

Djajaatmadja, Margono. 1940. Ngulandara. Jakarta: Bale Poestaka.

Djajalana, R,Ng.1933. Pesanggrahan Parangtritis.Jakarta: Bale Poestaka

Djajasoekarsa,LK. 1938. Sri Koemenjar. Jakarta: Bale Postaka.

Faruk.2002. Belenggu Pasca-Kolonial Novel-novel Indonesia Modern Tradisi Balai Pustaka dan Non-Balai Pustaka. Yogyakarta: Pustaka Pelajar..

Hardjadisastra,M.1932. Tri Djaka Moelja. Jakarta: Bale Postaka.

Hardjosoedjono, R.M. Sulardi. 1939. Sarwanto (Tjarios KaboedajanRoman).Solo: Drukkerij Marsch

Jasawidagda. R.Ng. 1938. Ni Woengkoek Bendha Growong. Jakarta: Bale Poestaka.

Jasawidagda, R.Tg. 1938. Peti Wasijat. Jakarta: Bale Poestaka.

Kartawibawa,R. 1933. Bakda mawi Rampog. Jakarta: Bale Postaka.

Koesoemadigda. 1922. Gawaning Wewatekan. Jakarta: Bale Poestaka.

Kramer, JG. 1937. Dados Tawanan Tigawelas Taoen. Jakarta: Bale Poestaka

Sastradiardja, R.Soeratman. 1923. Soekatja. Jakarta: Bale Poestaka

Sastradihardja. 1926. Soewarsa-warsijah. Jakarta: Bale Poestaka

Sastramintardja. 1922. Sendang ing Tawoen. Jakarta: Bale Poestaka

Soekarna. 1920. Pantja Kawarna. Jakarta: Bale Poestaka.

Soelardi, RB.1920.Serat Riyanto. Jakarta: Bale Poestaka.

Soewignja, Kedjora. 1932. Koerbaning Katresnan. Jakarta: Bale Poestaka.

Wirjaharsana, Soeradi. 1935. Wisaning Agesang. Jakarta: Bale Poestaka.

Zoetmulder, PJ.kalangwan: Sastra Jawa Kuno Selayang Pandang.Jakarta: Djambatan 